\title{
POLA PEMBINAAN STRATEGIS PEMUDA DI WILAYAH PELAYANAN MANADO MAPANGET TUMPA KOTA MANADO
}

\author{
Joupy Gustaf Zumondak Mambu \\ Universitas Negeri Manado \\ joupymambu31@gmail.com
}

\begin{abstract}
Abstrak
Program penyuluhan ini bertujuan untuk menyikapi berbagai permasalahan generasimuda yang muncul pada saat ini antara lain: Dirasa menurunnya jiwa idealisme, patriotisme, dan nasionalisme di kalangan masyarakat termasuk generasi muda. Kekurangpastian yang dialami oleh generasi muda terhadap masa depannya. Belum seimbangnya antara jumlah generasi muda dengan fasilitas pendidikan yang tersedia, baik yang formal maupun non formal. Tingginya jumlah putus sekolah yang diakibatkan oleh berbagai sebab yang bukan hanya merugikan generasi muda sendiri, tetapi juga merugikan seluruh bangsa. Kurangnya lapangan kerja / kesempatan kerja serta tingginya tingkat pengangguran /setengah pengangguran di kalangan generasi muda dan mengakibatkan berkurangnya produktivitas nasional dan memperlambat kecepatan laju perkembangan pembangunan nasional serta dapat menimbulkan berbagai problem sosial lainnya. Kurangnya gizi yang dapat menyebabkan hambatan bagi perkembangan kecerdasan dan pertumbuhan badan di kalangan generasi muda, hal tersebut disebabkan oleh rendahnya daya beli dan kurangnya perhatian tentang gizi dan menu makanan seimbang di kalangan masyarakat yang berpenghasilan rendah.
\end{abstract}

Kata kunci : Pola, Pembinaan, pemuda. 


\section{PENDAHULUAN}

Generasi muda merupakan generasi penerus perjuangan bangsa dan sumber daya insani bagi pembangunan nasional, generasi muda diharapkan dapat memikul tugas dan tanggung jawab untukkelestarian kehidupan bangsa dan negara. Untuk itu generasi muda perlu mendapatkan perhatian khusus dan kesempatan yang seluas-luasnya untuk dapat tumbuh dan berkembang cara wajar baik jasmani, rohani maupun sosialnya.

Pola dasar pembinaan dan pembangunan generasi muda ditetapkan oleh menteri Pendidikan dan Kebudayaan. Tujuannya agar semua pihak yang turut serta dan berkepentingan dalam penanganannya benar-benar menggunakannya sebagai pedoman sehingga pelaksanaannya dapat terarah, menyeluruh dan terpadu serta dapat mencapai sasarandantujuanyangdimaksud. Pola dasar pembinaan dan pengembangan generasi muda disusun berlandaskan:

A. Landasan idil (Pancasila)

B. Landasan Konstitusional (UUD 1945)

C. Landasan Histories (Sumpah Pemuda dan Proklamasi)

D. Landasan Normatif (Tata Nilai diTengah Masyarakat)

Motivasi asas pembinaan dan pengembangan generasi muda bertumpu pada strategi pencapaian tujuan nasional, seperti disebutkan dalam pembukaan UUD 1945 alinea keempat.
Atas dasar kenyataan ini, diperlukan penataan kehidupan pemuda sehingga mereka mampu memainkan peranan yang penting dalam masa depan sekalipun disadari bahwa masa depan tersebut tidak berdiri sendiri. Masa depan adalah lanjutan masa sekarang, dan masa sekarang adalah hasil masa lampau. Dalam hal ini, pembinaan dan pengembangan generasi muda haruslah menanamkan motivasi kepekaan terhadap masa datang sebagai bagian mutlak masa kini. Kepekaan terhadap masa yang akan datang membutuhkan pula situasi-situasi lingkungan untuk merelevansikan partisipannya dalam setiap kegiatan bangsa dan negara. Untuk itu, kualitas kesejahteraan yang membawa nilai-nilai dasar bangsamerupakan faktor penentu yang mewarnai pembinaan generasi muda dan bangsa Indonesia. Dalam hal ini, pembinaan dan pengembangan generasi muda menyangkut dua pengertian pokok, diantaranya:

A. Generasi muda sebagai objek pembinaan dan pengembangan adalah mereka yang telah memiliki bekal dan kemampuan serta landasan untuk mandiri dan keterlibatannya pun secara fungsional bersama potensi lainnya guna menyelesaikan masalah yang dihadapi. B. Generasi muda sebagai objek pembinaan dan pengembangan adalah mereka yang masih memerlukan pembinaan dan pengembangan kearah pertumbuhan 
potensi dan kemampuan ketingkat yang optimal dan belum dapat bersikap mandiri yang melibatkan secara fungsional.

Tanpa keikut sertaannya generasi muda, tujuan pembangunan ini akan sangat sulit sekali tercapai. Hal ini bukan saja karena p[emuda merupakan lapisan masyarakat yang cukup besar, tetapi tanpa kegairahan dan kreativitas mereka, pembangunan jangka panjang dapat kehilangan keseimbangan. Apabila pemuda masa sekarang terpisah dari persoalan masyarakatnya, sulit terwujud pemimpin masa datang yang dapat memimpin bangsanya sendiri.

Apabila kita melihat lebih dalam lagi di dalam dinamika kehidupan yang dialami oleh pemuda, sangatlah perlu mendapatkan perhatian. Pemuda harus di bina dengan sungguh-sungguh agar memiliki motivasi dan karakternya bertumbuh dan menunjukkan pertumbuhan di dalam kerohanian setiap pemuda. Menurut Kamus Besar Bahasa Indonesia, Pembinaan adalah "Suatu usaha, tindakan, dan kegiatan yang dilakukan secara efisien dan efektif untuk memperoleh hasil yang lebih baik".

Sehubungan dengan hal itu dapat dikatakan bahwa pembinaan itu adalah tindakan yang dilakukan sekelompok manusia untuk dapat bertingkah laku lebih baik. Pembinaan bukan hanya bersifat jasmani saja, tetapi juga bersifat hal yang rohani sebagaimana dikatakan dalam UUD 1945, yaitu: "Pembinaan itu merupakan bagian dari upaya peningkatan kualitas Indonesia, baik jasmani maupun rohani atas seluruh masyarakat".

Berdasarkan hal tersebut, dapat dikatakan bahwa pembinaan adalah sebagai tindakan dan upaya dalam meningkatkan kualitatif kerohanian sebaik mungkin yang telah menerima pembinaan yang baik akan terlihat dari gaya hidupnya sehari-hari. Pembinaan mengandung suatu maksud untuk mengusahakan sesuatu lebih baik, semakin meningkat, semakin maju dan berkualitas.

Dalam realitas kehidupan pemuda, secara terus menerus banyak mengalami pembaharuan. Pembaharuan yang dimaksud ialah adanya proses pertumbuhan kerohanian para pemuda ditengah-tengah gereja ataupun jemaat. Apabila pemuda tidak mendapat suatu pembinaan secara motivasi dan karakter dengan baik, maka mereka akan hidup menurut cara ataupun prinsip mereka masing-masing. Dalam Amsal 22:6, dikatakan "Didiklah orang muda menurut jalan yang patut baginya, maka pada masa tuanya pun ia tidak akan menyimpang dari pada jalan itu". Dalam ayat ini sangat jelas sekali dikatakan bahwa pemuda sangat perlu dibina atau dengan kata lain di didik agar pada masa hidup mereka selalu terbina oleh Firman Tuhan.

Generasi muda adalah bagian yang tidak terpisahkan dari pembangunan bangsa dan negara, dan diharapkan mampu 
menjadi pilar yang kokoh untuk menunjang kelangsungan hidup bangsa. Generasi muda sebagai generasi penerus diyakini menjadi faktor determinan bagi tumbuh kembangnya bangsa dan negara Indonesia sepanjang jaman, mampu menjadi pemimpin berkualitas, beretika, dapat menjadi contoh dan teladan yang baik, berkarakter kuat untuk mewujudkan visi yang dijadikan sebagai batu penjuru bagi seorang pemimpin.Persoalannya dewasa ini bangsa Indonesia tidak saja minus pemimpin yang mumpuni, berkualitas sehingga mampu memberi perubahan diberbagai organisasi termasuk organisasi keagamaan/gereja.Kualitas kepemimpinan tentu saja tidak dapat dipisahkan kualitas personal dan kemampuan untuk meyakinkan orang lain, dan dibarengi dengan moralitas, integritas, akseptabilitas, komitmen, dan atribut-atribut kepemimpinan lainnya.

Menurut Maxwell bahwa kepemimpinan adalah memberi pengaruh tidak lebih tidak kurang.Kemudian Waldock dan Kelly-Rawat berpendapat bahwa pengaruh adalah jantung kepemimpinan (Tjiharjadi dkk, 2012).Kepemimpinan dalam hal ini lebih terkait dengan kemampuan pemimpin untukmempengaruhi orang laindalam rangka mencapai tujuan.

Buha adalah salah satu kelurahan di Kecamatan Mapanget Manado yang masyarakatnya sangat
majemuk.Mengupayakan kebersamaan dalam masyarakat majemuk bukanlah perkara mudah, tetapi merupakan agenda penting yang harus terus dibina dan ditumbuhkan, karena rentan menimbulkan permasalahan sosial sekaligus ancaman serius bagi keamanan dan ketertiban masyarakat lebih khusus generasi muda. Aaksi kebut-kebutan, ugal-ugalan di jalan, mabuk-mabukan, pencurian, berkurangnya sopan santun, serta pengabaian akan aturan ditambah lagi dengan pengaruh globalisasi kehidupan yang semakin meluas.

$$
\text { Kondisi tersebut menjadi }
$$
penghambat sekaligus ancaman bagi generasi muda umumnya dan pemuda gereja khususnya, sehingga mengakibatkan kesulitan dalam mengembangkan kemandirian, dan mengaktualisasikan potensi yang dimilikinya. Nilai-nilai agama dan budaya belum sepenuhnya dijadikan sumber etika dalam kehidupan bemasyarakat.Berdasarkan analisis situasi dapat diketahui bahwa: a) Umumnya pengetahuan, kemampuan dan keterampilan pemuda gereja masih kurang memadai; b). Potensi pemuda gereja belum dimaksimalkan; dan c) Nilai-nilai agama, budaya kurang dijadikan sumber etika dan moral dalam pergaulan.Adapun permasalahannya difokuskan pada: 1) Bagaimana pola pembinaan strategis pemuda di wilayah pelayanan Manado mapanget Tumpa ? 2) Apa yang menjadi penghambat dalam mengembangkan 
kemandirian dan mengaktualisasikan potensi yang dimiliki pemuda gereja?

\section{KAJIAN PUSTAKA}

\section{Pola Pembinaan}

Pemuda harus dibina dengan baik agar menjauhkan diri dari dunia dan dosa, mempersatukan diri dengan kematian dan kebangkitan Kristus, menyerahkan dan mempersembahkan diri kepada Allah. Dengan kata lain, punya persekutuan yang intim dengan Kristus (I Yohanes 2:15-17). Bukan karena kemampuan orang percaya mempertahankan diri kudus dan suci dihadapan Tuhan melainkan oleh karena Firman Tuhan itu sendiri yang memampukan (Mazmur 119:9).

$$
\text { Dalam situasi dinamika }
$$
perkembangan dan kemajuan dunia sekarang, warga gereja perlu mendapatkan pembinaan yang baik melalui lembaga atau pun orang-orang yang berwenang bertindak sebagai pembina-pembina rohani. Gereja yang tidak melaksanakan pembinaan secara maksimal terhadap pemudanya, maka sesungguhnya gereja itu telah kehilangan eksistensinya sebagai fungsi yang sebenarnya. Kehadiran gereja di tengahtengah dunia ini punya misi yang jelas diberikan Tuhan Yesus Kristus yaitu menjadi garam dan terang dan membawa jiwa-jiwa kepada Yesus Kristus.

Pembinaan dapat dicapai melalui proses belajar mengajar untuk membawa jemaat kepada tingkat pengertian yang benar akan Firman Tuhan, sikap dan perbuatan yang sudah diperbaharui akan menggambarkan kedewasaan kerohanian di dalam Kristus. Jadi dalam hal ini, bahwa setiap orang percaya yang sudah lahir baru dan menjadi anggota keluarga Allah wajib mengikuti pembinaan tanpa ada batas, supaya setiap orang percaya tidak diombang-ambingkan dalam pengajaranpengajaran yang menyesatkan (Efesus 4:11), sehingga menghambat pertumbuhan kerohanian pemuda untuk melakukan pelayanan kelak.

Gereja dalam pelaksanaan pembinaan terhadap pemuda dapat dilakukan dengan pembinaan secara motivasi dan karakter. Walaupun metode dan cara pembinaan begitu luas namun hal itu tidak cukup untuk lebih efektif dan efisien dalam mendewasakan kerohanian para pemuda. Itu sebabnya pemuda perlu dibina dengan baik dan di didik, agar pemuda mempunyai motivasi yang jelas dan juga memiliki karakter yang baik dalam kehidupannya.

Dengan melalui pembinaan secara motivasi dan karakter yang baik dan benar, maka kehidupan pertumbuhan kerohanian pemuda semakin meningkat dan semakin percaya untuk lebih meyakini Allah dan Firman-Nya yang hidup dan berkuasa dan dapat hidup serta memegang janji-janjinya 
yang berpusatkan pada Kristus Yesus berdasarkan ajaran-ajaran Alkitab serta menghubungkan Firman Allah dengan kehidupan para pemuda.

Pola Dasar Pembinaan dan Pengembangan Generasi Pemuda adalah: Pola dasar pembinaan dan pembangunan generasi muda ditetapkan oleh Menteri Pendidikan dan Kebudayaan dalam Keputusan Menteri Pendidkan dan Kebudayaan nomor : 0323/U/1978 tanggal 28 oktober 1978. Tujuannya agar semua pihak yang turut serta dan berkepentingan dalam poenanganannya benar-benar menggunakannya sebagai pedoman sehingga pelaksanaanya dapat terarah, menyeluruh dan terpadu serta dapat mencapai sasaran dan tujuan yang dimaiksud.

Pola dasar pembinaan dan pengembangan generasi muda disusun berlandaskan: - Landasan Idiil : Pancasila - Landasan Konstitusional : Undang-undang dasar

- Landasan Histories : Sumpah Pemuda dan Proklamasi

- Landasan Normatif : Tata nilai ditengah masyarakat.

Arah pembinaan dan pengembangan generasi muda ditunjukan pada pembangunan yang memiliki keselarasn dan keutuhan antara ketiga sumbu orientasi hidupnya yakni.

- Orientasi ke atas kepada Tuhan Yang Masa
Esa.

- Orientasi dalam dirinya sendiri. - Orientasi ke luar hidup di lingkungan. Dalam hal ini, pembinaan dan pengembangan generasi muda menyangkut dua pengertian pokok, yaitu: - Generasi muda sebagai subjek pembinaan dan pengembangan adalah mereka yang telah memiliki bekal dan kemampuan serta landasan untuk mandiri dan ketrlibatannya pun secara fungsional bersama potensi lainnya guna menyelesaikan masalahmasalah yang dihadapi bangsa. - Generasi muda sebagai objek pembinaan dan pengembangan adalah mereka yang masih memerlukan pembinaan dan pengembangan kea rah pertumbuhan potensi dan kemampuan ketingkat yang optimal dan belum dapat bersikap mandiri yang melibatkan secara fungsional.

Pengertian pokok pembinaan dan pengembangan generasi muda Generasi merupakan generasi penerus perjuangan bangsa dan sumber daya insani bagi pembangunan nasional, diharapkan mampu memikul tugas dan tanggung jawab untuk kelestarian kehidupan bangsa dan negara. Untuk itu generasi muda perlu mendapatkan perhatian khusus dan kesempatan yang seluas- luasnya untuk dapat tumbuh dan berkembang secara wajar baik jasmani, rohani maupun sosialnya.

Dalam proses pertumbuhan dan 
perkembangannya, terdapat generasi muda yang menyandang permasalahan sosial seperti kenakalan remaja, penyalahgunaan obat dan narkota, anak jalanan dan sebagainya baik yang disebabkan oleh faktor dari dalam dirinya (internal) maupun dari luar dirinya (eksternal). Oleh karena itu perlu adanya upaya, program dan kegiatan yang secara terus menerus melibatkan peran serta semua pihak baik keluarga, lembaga pendidikan, organisasi pemuda, masyarakat dan terutama generasi muda itu sendiri.

Arah kebijakan pembinaan generasi muda dalam pembangunan nasional menggariskan bahwa pembinaan perlu dilakukan dengan mengembangkan suasana kepemudaan yang sehat dan tanggap terhadap pembangunan masa depan, sehingga akan meningkatkan pemuda yang berdaya guna dan berhasil guna. Dalam hubungan itu perlu dimantapkan fungsi dan peranan wadah-wadah kepemudaan seperti KNPI, Pramuka, Karang Taruna, Organisasi Siswa Intra Sekolah (OSIS), Organisasi Mahasiswa di lingkungan perguruan tinggi dan organisasi fungsional pemuda lainnya. Dalam kebijakan tersebut terlihat bahwa KARANG TARUNA secara ekslpisit merupakan wadah pembinaan dan pengembangan generasi muda yang bertujuan untuk mewujudkan generasi muda aktif dalam pembangunan nasional pada umumnya dan pembangunan bidang kesejahteraan sosial pada khususnya. Salah satu kegiatan Karang Taruna Kelurahan Purwaharja Kecamatan Purwaharja sedang membuat kerajinan bambu yang diolah menjadi aneka macam alat musik seperti suling, angklung dan sebagainya.

\section{Kepemimpinan}

Kepemimpinan dapat terjadi diberbagai lembaga atau organisasi, baik pada organisasi pemerintah, swasta, militer, maupun sosial keagamaan/gereja.Bahkan kepemimpinan dapat dimiliki oleh orang yang bukan pemimpin. Menurut Yulk (2010) "kepemimpinan berkaitan dengan proses yang disengaja dari seseorang untuk menekankan pengaruhnya yang kuat terhadap orang lain untuk membimbing, membuat struktur, memfasilitasi aktivitas dan hubungan di dalam kelompok atau organisasi".Hughes et al sebagaimana dijelaskan Tjiharjadi (2012) bahwa kepemimpinan adalah "suatu proses mempengaruhi sebuah kelompok yang terorganisir untuk mencapai tujuan mereka". Pendapat-pendapat tersebut menunjukkan bahwa ada beberapa aspek penting yang terkandung di dalamnya: 1) manusia (pemimpin dan yang dipimpin); 2) sarana (organisasi) dan 3) tujuan yanag akan dicapai. Jadi kepemimpinan berkaitan dengan kemampuan, kecakapan dan keterampilan yang dimiliki seseorang untuk mempengaruhi orang di dalam organisasi yang terorganisir.Mempengaruhi merupakan suatu tindakan dari seorang 
pemimpin agar yang dipimpin berperilaku sesuai dengan harapan.

$$
\text { MenurutWirawan }
$$

"kepemimpinan sebagai proses pemimpin menciptakan visi dan melakukan interaksi saling memengaruhi dengan para pengikutnya untuk merealisasi visi".Kepemimpinan dapat diartikan sebagai kapasitas yang dimiliki seseorang dalam menerjemahkan visinya ke dalam realitas. Untuk merealisasikan visi berarti melibatkan orang lain di dalamnya. Merelisasikan visi merupakan tujuan utama kepemimpinan, dan keberhasilan kepemimpinan akan tergambar pada terealisasinya visi tersebut. Kepemimpinan pada dasarnyaberkaitan dengan kemampuan dan proses mempengaruhi dari seorang pemimpin kepada yang dipimpin untuk merealisasikan visinya. Mempengaruhi sebagai proses untuk mengubah sikap, pola pikir, dan perilaku seseorang agar mau bergerak ke arah pencapaian tujuan yang sudah ditetapkan.Hal ini dapat dimaklumi karena kunci utama dari kepemimpinan adalah pemimpin.Danmempengaruhi adalah inti dari kepemimpinan.

Kepemimpinan seseorang tidak akan lepas dari gaya yang digunakan pada saat menjalankan aktivitasnya dalam kelompok atau organisasi yang dipimpinnya. Beberapa orang merasa yakin bahwa kepemimpinan yang efektif bergantung pada sifat dan perilaku tertentu secara terpisah maupun gabungan. Orang lainnya yakin bahwa satu gaya kepemimpinan efektif digunakan untuk semua situasi. Namun masih ada orang lain lagi yang yakin bahwa tiap situasi memerlukan satu gaya kepemimpinan. Gaya kepemimpinan adalah norma perilaku yang digunakan oleh seseorang pada saat orang tersebut mencoba mempengaruhi perilaku orang lain seperti yang ia lihat (Thoha, 2011). Gaya kepemimpinan berarti cara/pola yang digunakan seseorang ketika berinteraksi dan mmempengaruhi perilaku orang lain agar bertindak sesuai yang diinginkannya.

Kepemimpinan akan selalu terkait dengan pemimpin dengan yang dipimpin, sehingga perlu pemimpin yang bermoral. Pemimpin bermoral berupaya menjadikan yang dipimpin sebagai orang yang beretika sehingga menjadi panutan.Pemimpin merupakan role model bagi pengikutnya yang mampu mendemonstrasikan perilaku etis dalam setiap tindakan.Pemimpin adalah penentu bagi terciptanya perilaku etis dalam organisasi.Oleh karena itu pemimpin harus mampu menciptakan iklim etis dalam organisasi yang memenuhi standar`etika.Etika mempengaruhi perilaku baik pemimpin maupun yang dipimpin.

Manusia sebagai umat ciptaan Allah dianugerahkan kemampuan dan potensi untuk memimpin yang perlu digali dan dikembangkan. Pemuda gereja adalah aset yang sangat berharga bagi gereja, 
masyarakat dan bangsa.Oleh sebab itu pemuda gereja perlu mengenali potensi yang dimilikinya, termasuk potensi memimpin. Pemuda gereja tidak saja terlahir sebagai pemimpin, tetapi dibentuk menjadi pemimpin sehingga perlu mengembangkan dan menggunakan karunia memimpin untuk memberkati orang lain.

\section{Kepemimpinan Pelayan}

Kepemimpinan Kristiani adalah kepemimpinan yang menerapkan ajaran Kristiani, dengan semangat melayani berdasarkan kasih, mempengaruhi melalui sikap dan teladan.Pemimpin yang sukses dalam perspektif Kristen adalah pemimpin yang memahami bahwa kepada dirinya diberikan Tuhan karunia untuk memimpin.Kepemimpinan kristiani samadengan konsep kepemimpinan lainnya. Yang membedakanadalah penekanan pada proses mencapai tujuan, yakni pelayanan berdasarkan kasih sesuai ajaran Yesus Kristus. Menurut Hector Ruiz bahwa "inti tugas pemimpin adalah melayani. Pemimpin terbaik adalah pelayan terbaik". Robert K. Greenleaf menyatakan bahwa "kepemimpinan pelayan adalah model kepemimpinan yang memprioritaskan pelayanan kepada pihak lain, baik kepada pegawai (anggota) organisasi, pelanggan, maupun kepada masyarakat. Model kepemimpinan pelayan esensinya adalah melayani orang lain, yaitu pelayanan kepada pegawai, pelanggan, dan masyarakat, sebagai prioritas utama" (Sedarmayanti, 2010).Jadi pemimpin pelayan mengandung arti pemimpin yang melayani.Karena melayani adalah tugas utama pemimpin, termasuk memberdayakan dan menjadikan bawahan sebagai prioritas dan teman sekerja.

\section{METODE PELAKSANAAN}

Metode yang digunakan dalam mengungkap permasalahan adalah pendekatan kualitatif dengan analisis model interaktif dari Miles dan Huberman (2007).Untuk mendapatkan data-data terkait dengan fokus permasalahan, maka ditempuh beberapa tahapan. Tahap pertama yang dilakukan adalah berkonsultasi dengan Badan Pekerja Majelis Jemaat (BPMJ) Eben Haezer Camar Buha ; dan Ketua/Penatua Pemuda Jemaat untuk mendapatkan data tentang kepemimpinan pemuda gereja; b) Melakukan pendataan kondisi pemuda gereja dan permasalahan kepemimpibnan; c) Melakukan wawancara dengan beberapa anggota pemuda dan beberapa koordinator pemuda. Tahap berikutnya melalukan identifikasi tentang faktor-faktor yang menjadi penghambat dalam mengembangkan kemandirian dan mengaktualisasikan potensi yang dimiliki pemuda gereja Jemaat Eben Haezer Camar Buha. 


\section{HASIL DAN PEMBAHASAN}

1. Masalah-Masalah Generasi Muda / Pemuda

Berbagai permasalahan generasi muda / Pemuda yang muncul pada saat ini antara

lain:

- menurunnya jiwa idealisme, patriotisme, dan nasionalisme di kalangan masyarakat termasuk generasi muda.

- Kekurangpastian yang dialami oleh generasi muda terhadap masa depannya.

- Belum seimbangnya antara jumlah generasi muda dengan fasilitas pendidikan yang tersedia, baik yang formal maupun non formal. Tingginya jumlah putus sekolah yang diakibatkan oleh berbagai sebab yang bukan hanya merugikan generasi muda sendiri, tetapi juga merugikan seluruh bangsa. - Kurangnya lapangan kerja / kesempatan kerja serta tingginya tingkat pengangguran /setengah pengangguran di kalangan generasi muda dan mengakibatkan berkurangnya produktivitas nasional dan memperlambat kecepatan laju perkembangan pembangunan nasional serta dapat menimbulkan berbagai problem sosial lainnya. - Kurangnya gizi yang dapat menyebabkan hambatan bagi perkembangan kecerdasan dan pertumbuhan badan di kalangan generasi muda, hal tersebut disebabkan oleh rendahnya daya beli dan kurangnya perhatian tentang gizi dan menu makanan seimbang di kalangan masyarakat yang berpenghasilan rendah. - Pergaulan bebas yang membahayakan sendi-sendi perkawinan dan kehidupan keluarga.

- Meningkatnya kenakalan remaja/pemuda termasuk penyalahgunaan narkotika. Dan ada juga masalah lain yaitu: - Kebutuhan Akan Figur Teladan Remaja jauh lebih mudah terkesan akan nilai-nilai luhur yang berlangsung dari keteladanan orang tua mereka daripada hanya sekedar nasihat-nasihat bagus yang tinggal hanya kata-kata indah. - Sikap Apatis Sikap apatis meruapakan kecenderungan untuk menolak sesuatu dan pada saat yang bersamaan tidak mau melibatkan diri di dalamnya. Sikap apatis ini terwujud di dalam ketidakacuhannya akan apa yang terjadi di masyarakatnya. - Kecemasan dan Kurangnya Harga Diri Kata stess atau frustasi semakin umum dipakai kalangan remaja. Banyak kaum muda yang mencoba mengatasi rasa cemasnya dalam bentuk "pelarian" (memburu kenikmatan lewat minuman keras, obat penenang, seks dan lainnya).

- Ketidakmampuan untuk Terlibat Kecenderungan untuk mengintelektualkan segala sesuatu dan 
pola pikir ekonomis, membuat para remaja sulit melibatkan diri secara emosional maupun efektif dalam hubungan pribadi dan dalam kehidupan di masyarakat. Persahabatan dinilai dengan untung rugi atau malahan dengan uang. - Perasaan Tidak Berdaya Perasaan tidak berdaya ini muncul pertama-tama karena teknologi semakin menguasai gaya hidup dan pola berpikir masyarakat modern. Teknologi mau tidak mau menciptakan masyarakat teknokratis yang memaksa kita untuk pertama-tama berpikir tentang keselamatan diri kita di tengah2 masyarakat. Lebih jauh remaja mencari "jalan pintas", misalnya menggunakan segala cara untuk tidak belajar tetapi mendapat nilai baik atau ijasah. - Pemujaan Akan Pengalaman Sebagian besar tindakan-tindakan negatif anak muda dengan minumam keras, obat-obatan dan seks pada mulanya berawal dari hanya mencobacoba. Lingkungan pergaulan anak muda dewasa ini memberikan pandangan yang keliru tentang pengalaman.

2. Kepemimpinan Pemuda Gereja

Kepemimpinan dapat terjadi diberbagai lembaga atau organisasi, baik pada organisasi pemerintah, swasta, militer, maupun sosial keagamaan/gereja.Bahkan kepemimpinan dapat dimiliki oleh orang yang bukan pemimpin. Menurut Yulk (2010) "kepemimpinan berkaitan dengan proses yang disengaja dari seseorang untuk menekankan pengaruhnya yang kuat terhadap orang lain untuk membimbing, membuat struktur, memfasilitasi aktivitas dan hubungan di dalam kelompok atau organisasi". Hughes et al sebagaimana dijelaskan Tjiharjadi (2012) bahwa kepemimpinan adalah "suatu proses mempengaruhi sebuah kelompok yang terorganisir untuk mencapai tujuan mereka". Aspek penting yang terkandung di dalamnya: 1) manusia (pemimpin dan yang dipimpin); 2) sarana (organisasi) dan 3) tujuan yanag akan dicapai. Jadi kepemimpinan dalam hal ini berkaitan dengan kemampuan, kecakapan dan keterampilan yang dimiliki seseorang untuk mempengaruhi orang di dalam organisasi yang terorganisir.Mempengaruhi merupakan suatu tindakan dari seorang pemimpin agar yang dipimpin berperilaku sesuai dengan harapan.

Sedangkan menurut Wirawan (2013) bahwa "kepemimpinan sebagai proses pemimpin menciptakan visi dan melakukan interaksi saling memengaruhi dengan para pengikutnya untuk merealisasi visi". Kepemimpinan dapat diartikan sebagai kapasitas yang dimiliki seseorang dalam 
menerjemahkan visinya ke dalam realitas. Untuk merealisasikan visi berarti melibatkan orang lain di dalamnya. Merelisasikan visi merupakan tujuan utama kepemimpinan, dan keberhasilan kepemimpinan akan tergambar pada terealisasinya visi tersebut. Kepemimpinan pada dasarnya berkaitan dengan kemampuan dan proses mempengaruhi dari seorang pemimpin kepada yang dipimpin untuk merealisasikan visinya. Proses mempengaruhi sebagai proses untuk mengubah sikap, pola pikir, dan perilaku seseorang agar mau bergerak ke arah pencapaian tujuan yang sudah ditetapkan.

Hasil temuan dan wawancara diperoleh data bahwa kepemimpinan pada pemuda gereja di Jemaat Eben Haezer Buha berupaya menyelaraskan kepentingan dan tujuan pribadi dengan kepentingan dan tujuan organisasi melalui musyawarah, berupaya menjadikan anggotanya meraih prestasi dengan menggali dan mengembangkan kapasitas dan potensi yang dimiliki.Gaya kepemimpinan yang demikian oleh Hicks \& Gullet (1987) menyebutnya gayademokrasi.Seorang pemimpin selain harus mampu mnjadikan orang yang dipimpin menjadi lebih baik, lebih sukses, tetapi juga terus belajar dengan berupaya mengembangkan kapasitas pribadinya sebagai pemimpin sehingga menjadi teladan bagi yang dipimpin.Gaya kepemimpinan adalah norma perilaku yang digunakan oleh seseorang pada saat orang tersebut mencoba mempengaruhi perilaku orang lain seperti yang ia lihat (Thoha, 2011). Kepemimpinan seseorang tidak akan lepas dari gaya yang digunakan saat menjalankan aktivitasnya dalam kelompok atau organisasi yang dipimpinnya. Gaya kepemimpinan dapat berarti cara/pola yang digunakan seseorang ketika berinteraksi dan mempengaruhi perilaku orang lain agar bertindak sesuai yang diinginkannya.

John C Maxwell berpendapat ada lima level kepemimpinan yang harus ditapaki, yaitu: Level pertama Position: menggunakan jabatan untuk mempengaruhi orang yang dipimpin; level kedua Permission: membangun hubungan adalah awal kepemimpinan sejati; level ketiga Production, yaitu menciptakan tim yang berprestasi; level keempat People Development. Saatnya melangkah dari seseorang yang berhasil memimpin tim yang berprestasi dan produktif menuju pengembangan budaya kepemimpinan. Dan level kelima adalah Pinnacle dengan mengembangkan budaya kepemimpinan (Majalah Inspirasi, Vol.34/Th. IV/2012).

Kepemimpinan yang baik bukan tentang peningkatan jabatan, tetapi lebih pada bagaimana pemimpin mampu mengembangkan orang yang dipimpin.Pendapat Maxwell tersebut memberikan inspirasi bahwa seorang pemimpin perlu mengembangkan dirinya sehingga mampu mencapai puncaknya. 
Menjalin hubungan dengan yang dipimpin menjadi penting, karena orang akan rela menerima kita sebagai pemimpin apabila hubungannya baik. Tetapi hubungan baik ternyata belum cukup, perlu juga menggunakan kompetensi, dan memberikan hasil sehingga dapat menambah reputasi dan kredibilitas kepemimpinan. Pada level people development meningatkan bahwa seorang pemimpin harus mampu melatih dan memperlengkapi pengikut menjadi pemimpin baru, tetapi juga ada pendelegasian tugas dan membagi tanggungjawab.Sedangan pada level Pinnacle adalah puncak kepemimpinan.Pemimpin dalam hal ini harus memiliki karakter yang matang dengan talenta alamiah, menjadi teladan, dan terampil melatih orang yang dipimpin menjadi pemimpin terbaik.

Pemuda gereja adalah pribadi yang memiliki kecakapan dan kelebihan serta potensi di dalam dirinya.Pengembangan potensi pribadi merupakan keharusan, karena setiap orang memiliki potensi termasuk menjadi pemimpin.Potensi merupakan benih karunia Allah yang perlu digali dan dikembangkan.Untuk menggali dan mengembangkan potensi pemuda gereja, maka Pimpinan Pemuda Gereja Masehi Injili di Minahasa (GMIM) Jemaat Eben Haezer melaksanakan berbagai kegiatan, antara lain Kesenian (Koor, vocal group), cerdas cermat dan kegiatan keagamaan lainnya termasuk di dalamnya Pelatihan Dasar Kepemimpinan Pemuda Gereja..

Untuk menjadi pemimpin Kristen yang ideal dalam konteks gereja adalah melayani.Melayani adalah inti dari kepemimpinan Kristiani. Menjadi pemimpin tidak selamanya memegang jabatan khusus, tetapi menjadi pemimpin juga ketika mampu mempengaruhi dan mengembangkan orang lain menjadi lebih baik. Kepemimpinan yang melayani senantiasa mengupayakan dan mengutamakan kepentingan orang yang dipimpin dibanding kepentingan pribadi. Kathleen Patterson menegaskan bahwa karakteristik pemimpin pelayan, adalah: 1) cinta kasih; 2) Rendah hati; 3) Altruisme (tindakan membantu orang lain secara tulus); 4) Memiliki visi; 5) Rasa Percaya; 6) Memberdayakan pihak lain; 7) Melayani. Pelayanan harus menjadi fungsi utama kepemimpinan, bukan berdasar kepentingan diri tetapi lebih mengarah pada kepentingan orang lain (Sedarmayanti, 2010).

Kepemimpinan Kristiani sudah semestinya mengutamakan pelayanan kepada sesama berdasarkan kasih dan ajaran Kristus, memiliki keberanian untuk mewartakan kabar gembira tentang keteladanan.Keteladanan diterjemahkan secara nyata ke dalam nilai-nilai sebagai dasar pijakan dari organisasi.Nilai-nilai tersebut dapat berupa penghargaan 
terhadap sesama, bekerja dengan sepenuh hati, jujur dan sebagainya.Jika seorang mengaku pemimpin yang menbawa napas Kristiani, tentu saja bertugas mewartakan nilai-nilai tersebut.Manusia diciptakan Allah menurut rupa dan gambar Allah, memiliki keunikan khusus.Karakter pemimpin Kristiani adalah keteladanan.yang ukurannya adalah model dan teladan Allah di dalam pribadi Yesus

Berdasarkan hasil yang diperoleh menunjukkan bahwa pemuda gereja memahami potensi yang dimiliki termasuk potensi menjadi pemimpin sebagai anugerah Allah yang perlu digali dan dikembangkan.Hanya saja dalam realisasinya belum sesuai dengan harapan.Mengenali potensi diri dan mengembangkannya sebagai seorang yang tidak saja terlahir sebagai pemimpin, tetapi dibentuk menjadi pemimpin serta menggunakan karunia sebagai anugerah agar menjadi berkat bagi orang lain. Di era global, peran pemuda gereja/pemimpin Kristensangat menentukan kemajuan bangsa, sebab itu pemimpin harus memiliki komitmen yang kuat terhadap apa yang diyakini agar mampu memberi pengaruh yang baik di lingkungan sekitar. Kepercayaan adalah landasan kepemimpinan, dan untuk membangun kepercayaan, maka pemimpin pemuda Kristen harus memberi teladan bukan saja dalam hal kemampuan, karakter, tetapi juga dalam hal etika. Dengan etika dan karakter yang baik akan tumbuh kepercayaan yang memungkinkan terjadinya kepemimpinan yang beretika.

\section{KESIMPULAN DAN SARAN}

1. Pola Pengembangan Stategis Pemuda perlu menjadi perhatian di Wilayah pelayanan Manado Mapanget Tumpa agar supaya lebih terarah dan mempunyai dampak yang positif.

2. Pembinaan dan pengembangan potensi angkatan muda pada tingkat perguruan tinggi, lebih banyak diarahkan dalam program-program studi dalam berbagai ragam pendidikan formal. Mereka dibina digembleng di laboratorium dan pada kesempatan praktek lapangan

\section{KEPUSTAKAAN}

Alwi, Syafaruddin, 2001. Manajeman Sumber Daya Manusia, Strategi Keunggulan Kompetitif, Badan Penerbit Fakultas Ekonomi. Yogyakarta.

Asmara, Drs. H. Sakhyan MSP, Desember 2013, Kebijakan Nasional Pembangunan Kepemudaan Menuju Pemuda Indonesia Yang Berkarakter, Jakarta.

Siagian Sondang P, 2004, Manajemen Sumber Daya Manusia, Penerbit PT Bumi Aksara.

Wahyudini, Siti S,P.,M.Si, Agustus 2011 Strategi Pengarusutamaan Pemuda : Mengggagas Partisipasi Pemuda dalam Pembangunan, Jakarta. 
Indonesia, Undang-Undang Dasar RI Tahun 1945

Undang-Undang Kepemudaan No.40 Tahun 2009

Miles M.B \& A.M Huberman.2007. Analisis Data Kualitatif. Buku Sumber Tentang Metode-Metode Baru. Penerjemah Tjetjep Rohendi Rohidi. Jakarta: UI Press.
Tjiharjadi Semuil, dkk. 2012. To be a Great Effective Leader. Yogyakarta: CV Andi Offset.

Wirawan. 2013. Kepemimpinan. Teori, Psikologi, Perilaku Organisasi, Aplikasi dan Penelitian. Jakarta: PT RajaGrafindo Persada.

Wiyono.Isbagyo.F.X.G. 2013.Christian Leadership.Gaya Kepemimpinan Kristiani Melayani dengan Kasih. Tangerang: Karunia Exori. 
Jurnal ABDIMAS, Vol. 12, No. 1, April 2019

ISSN: 1979-0953 | e-ISSN: 2598-6066 